\title{
The South Korean agri-food e-market: A comparative B2B e-commerce case study
}

Kyeong Ah Ahn ${ }^{1}$, Ik Hoon Jang ${ }^{2}$, Young Chan Choe ${ }^{3}$

\begin{tabular}{|c|c|}
\hline I N F O & A B S T R A C T \\
\hline Received & \\
\hline Accepted & This paper is a comparative case study for two B2B agri-food e-commerce examples and \\
\hline Available on-line & the exchange process analysis. Data were collected by interviews with \\
\hline Responsible Editor: & $\begin{array}{l}\text { operators and experts. The results for this study show that the } \mathrm{B} 2 \mathrm{~B} \text { e-commerce exchange } \\
\text { process can efficiently replace the traditional process. The reduction of costs in the }\end{array}$ \\
\hline $\begin{array}{l}\text { Keywords: } \\
\text { B2B, agri-food market, } \\
\text { exchange process, cost }\end{array}$ & $\begin{array}{l}\text { searching and valuation processes is a successful factor for the replacement. Also, } \\
\text { authentication process is important key to success. However, efficient delivery is not a } \\
\text { necessary condition. }\end{array}$ \\
\hline
\end{tabular}

\section{Introduction}

The characteristics of business-to-business (B2B) e-commerce, unlike business-to-consumer (B2C) e-commerce, include high trading volume and limited buyers and sellers (Rauyren and Miller, 2007; Mukhopadyay and Kekre, 2002). If businesses take advantage of B2B e-commerce as compared to traditional forms of trading, the number of B2B trades would increase (Kaplan and Sawhney, 2000).

Agricultural products are perishable commodities with characteristics that are not easy to standardize. There are diverse opinions of B2B e-commerce success in the agriculture and food (agri-food) market due to the characteristics of agricultural product. For example, logistic costs can decrease. If upstream logistics are separated, the direct delivery of agricultural products from producers to retailers is possible. However, searching costs can increase. Since the properties of agricultural product quality are unlikely to be standardized, an e-catalog cannot be a viable substitute for real products. Thus, we need to find suitable process improvement when considering actual B2B e-commerce practices.

Two South Korean agri-food market B2B e-commerce cases have produced different results. The B2B e-commerce of the school foodservice food market and the Garak wholesale market in Seoul both started in 2009. The B2B e-commerce trading volume reached $60 \%$ of the total school foodservice within the food sector at 1.8 billion US dollars (Agrinet, 2014). However, B2B e-commerce of the Garak wholesale market has remains at $1.5 \%$ of the total (Seoul agro-fisheries \& food corporation, 2013). Why have these two cases resulted in diverse performances?

This paper is a comparative case study for two B2B e-commerce agri-food market examples. The cases are analyzed using the exchange process framework of Kambil and Heck(1998) grounded in transaction cost theory and information process theory. Second chapter includes an explanation of

\footnotetext{
${ }^{1}$ Corresponding author, Kyeong Ah Ahn

Seoul National University, South Korea

minhui2@empas.com

${ }^{2}$ Ik Hoon Jang

Seoul National University, South Korea

iks0404@snu.ac.kr

${ }^{3}$ Young Chan Choe

Seoul National University, South Korea

aggi@snu.ac.kr
} 
research framework. Third and fourth chapters introduce two B2B e-commerce cases. Finally, a comparative case analysis is conducted using data collected by interviews with operators and experts.

\section{Analysis Framework}

Traditional process classifications of exchange include search, bargaining and negotiation, monitoring, and enforcement processes (Coase 1960; Dahlman 1979). However, there are sufficient details for market structure than for traditional process classification. Kambil and Heck (1998) identified ten processes that provide a basis for an analysis of efficiency after the adoption of B2B. The basic trade processes are search, valuation, logistics, payment and settlements, and authentication. The context processes are communication, product representation, legitimation, influence, and dispute resolution.

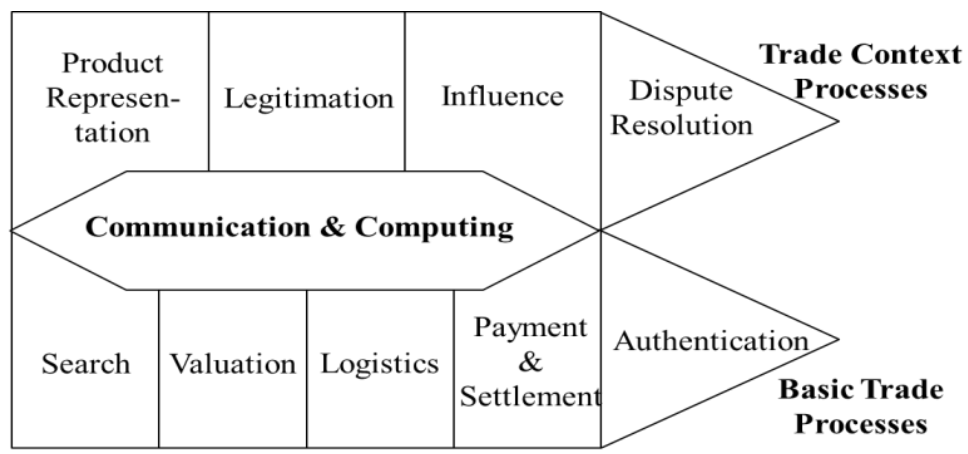

Figure 1. Exchange Processes (Kambil and Heck, 1998)

Ten exchange processes of Kambil and Heck (1997) are summarized as fallow. "Search" process is the information gathering and evaluation process undertaken by buyers and sellers to identify opportunities. "Valuation(Price Negotiation)" is the process and methods of negotiating and discovering a purchase or sale prices for a product. "Logistics" are the processes specifying and coordinating the actual delivery of goods from the seller to buyer. "Payment and Settlements" are processes define the terms and methods of payment permitted and ensure the settlement of payments in the exchange. "Authentication" is a core set of activities used to verify the quality and features of the product offered, the authenticity of the trading parties, and monitor conformance to the contract or agreement among parties.

"Communications and Computing" processes underlie and bind all trading processes. New communications capabilities in terms of richer media, faster transfer speeds, improved ease of use and lower infrastructure costs transform coordination capabilities within and across trade processes. "Product Representation" processes determine how the product attributes are specified to the buyer or other third parties. "Legitimation" process is used to validate the trade or exchange agreement. It defines how bids, or agreements are recognized as valid and binding commitments by exchange parties. "Influence" are processes implement mechanisms to enforce obligations or penalties to reduce opportunism risks. "Dispute Resolution" is related to provision of various processes for resolving disputes among parties and structures decision rights in the event of conflict.

\section{B2B e-commerce of School Foodservice}

In the early 2000s, Korean school foodservice had experienced a food safety crisis due to mass food poisoning, and the trust of school foodservice collapsed. After then, the transparency of food transactions has become an important factor to improve the school foodservice. The Korean government developed agri-food B2B e-commerce system which enables to inspect in advance of delivery and centrally control suppliers by an administrator of public corporation

Figure 2 is a transaction procedure of B2B e-commerce in school foodservice. School buyer includes processes of uploading instruction of stocks in trade, registering and notifying electronic bid, selecting successful bidder, and contract. Agri-food supplier includes processes of checking notice of a bid, bidding, entering final contract unit cost, and payment. In case of supplier, it is unique in that suppliers 
have to receive inspection by administration before having membership. The inspection is carried out regularly after obtaining membership.

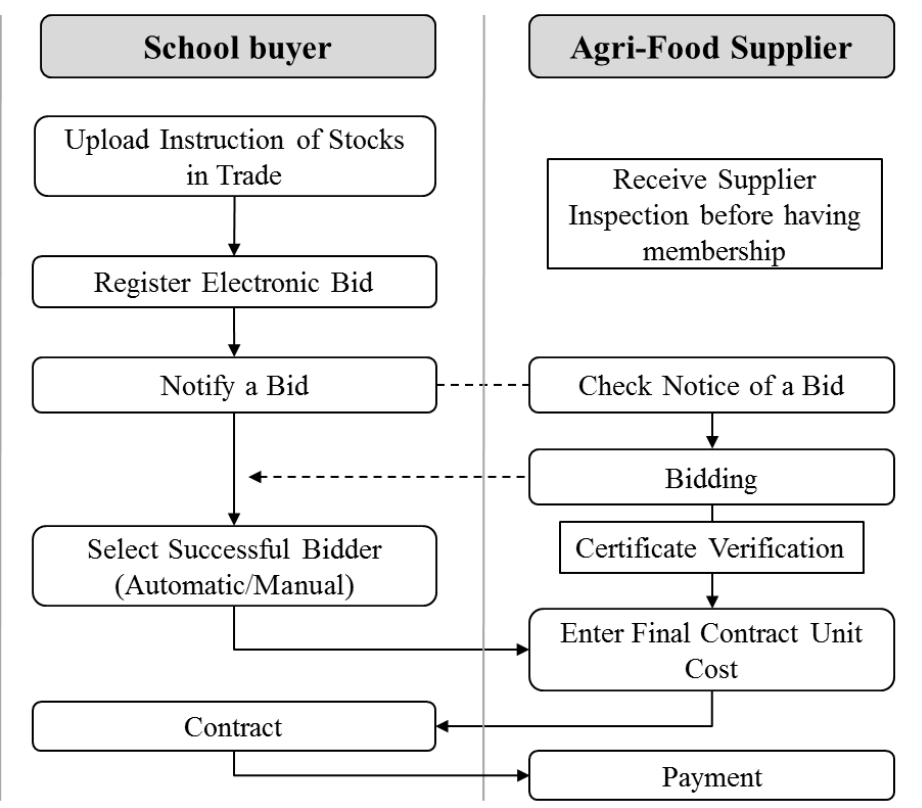

Figure 2. B2B E-Commerce Procedure of Schoolfood Service

\section{B2B e-commerce of Garak Wholesale Market}

Garak market is the biggest wholesale market in Korea, which is established in 1985 outside of downtown area of the capital city. This wholesale market handles 40 percent of total domestic agriproduct transactions. Transactions are mainly achieved by an auction system. Some of transactions with large amount are traded by price negotiation method to supplement the problem of auction system being vulnerable to price fluctuation. B2B e-commerce system was launched in 2009, and transactions by price negotiation has been traded on $\mathrm{B} 2 \mathrm{~B}$ e-commerce website. The benefit of transactions through $\mathrm{B} 2 \mathrm{~B}$ e-commerce is that products can be traded outside of market place, in contrast with offline transactions which are traded in the market place.

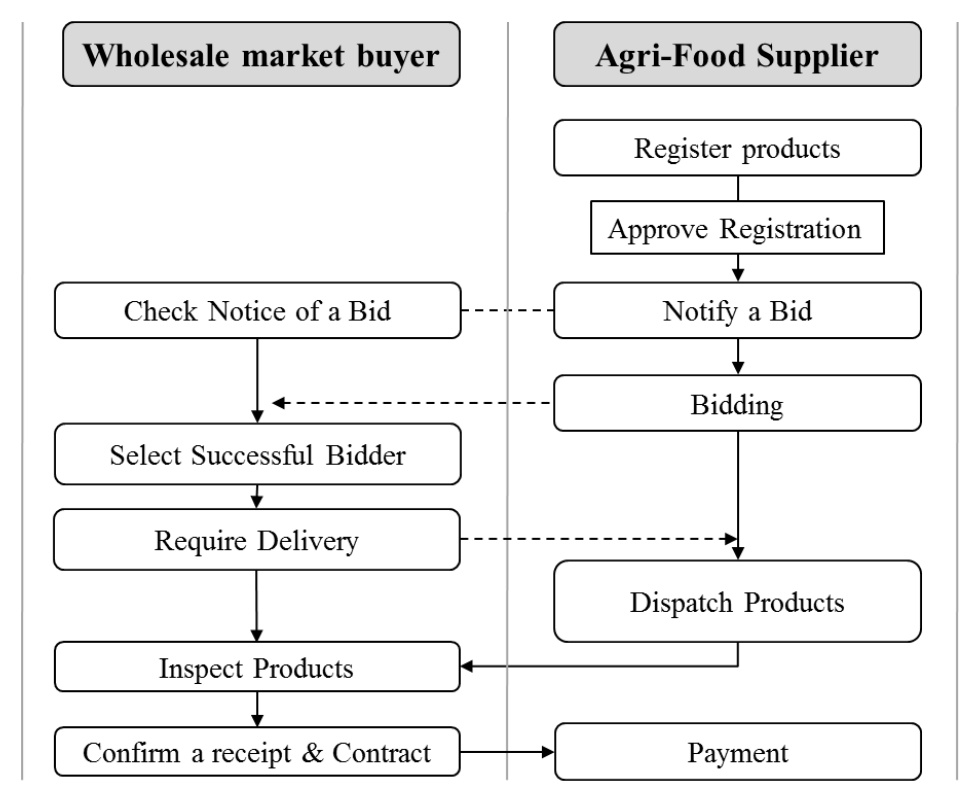

Figure 3. B2B E-Commerce Procedure of Garak Wholesale Market 
Figure 3 is transaction procedure of B2B e-commerce in Garak wholesale market. Wholesale market buyer includes processes of checking notice of a bid, selecting successful bidder, requiring delivery, inspecting products, and confirming a receipt and contract. Agri-food supplier includes registering products, notifying a bid, bidding, dispatching products, and payment. In case of supplier, it is unique in that middleman approves products registered by suppliers before notifying a bid. The approval is achieved for every transaction.

\section{Analysis Results}

Table 1 shows the analysis of the school foodservice food market and the Garak wholesale market $\mathrm{B} 2 \mathrm{~B}$ e-commerce cases based on the exchange process model. In case of the B2B e-commerce adoption in the school foodservice food sector, five exchange processes were changed. The searching and valuation processes are transformed from manual to automation, which decrease the order cost. In the authentication process, B2B e-commerce managers (public corporation administrators) inspect products of suppliers regularly, and recommend qualified products by certificate authority. An e-catalog of the B2B system includes much information such as price, cultivation, credit of supplier, certificate, logistics, and quality. These are differentiated from common e-catalogs because they generally show only product specification information. Thus, product representation through e-catalog with rich information reduce a cost for evaluating the desired quality. Communications of the B2B e-commerce system are improved from using telephone to utilizing the B2B system. However, there is no significant change in cost. Due to such changes, nutrition teachers were able to order food from the sellers within 1-2 days after the adoption of B2B e-commerce system, unlike 3-4 days before adoption.

Table 1. Exchage process comparision between school foodservice and wholesale market

\begin{tabular}{|c|c|c|c|c|}
\hline \multirow[t]{2}{*}{ Exchange process } & \multicolumn{2}{|c|}{$\begin{array}{c}\text { B2B in the school foodservice food } \\
\text { market } \\
\text { (Successful case) }\end{array}$} & \multicolumn{2}{|c|}{$\begin{array}{l}\text { B2B in the wholesale market } \\
\text { (Failure case) }\end{array}$} \\
\hline & What change & $\begin{array}{l}\text { Change in } \\
\text { cost }\end{array}$ & What change & $\begin{array}{l}\text { Change in } \\
\text { cost }\end{array}$ \\
\hline 1. Search & $\begin{array}{l}\text { Search each other on } \\
\text { B2B system }\end{array}$ & Decrease & No change & No change \\
\hline 2. Valuation & B2B system bidding & Decrease & No change & No change \\
\hline 3. Logistic & No change & No change & Direct delivery & Decrease \\
\hline 4. Payment & No change & No change & No change & No change \\
\hline 5. Authentication & $\begin{array}{l}\text { Regular inspection, } \\
\text { Association with } \\
\text { certificate authority }\end{array}$ & Decrease & $\begin{array}{l}\text { Inspection at } \text { from } \\
\text { marketplace } \\
\text { place of buyer }\end{array}$ & Decrease \\
\hline $\begin{array}{l}\text { 6. Communicatio } \\
\mathrm{ns}\end{array}$ & $\begin{array}{l}\begin{array}{l}\text { From by telephone to } \\
\text { through } \\
\text { system }\end{array} \\
\end{array}$ & No change & No change & No change \\
\hline \begin{tabular}{|l} 
7. \\
Product \\
representation
\end{tabular} & e- catalog & Decrease & No change & No change \\
\hline 8. Legitimation & No change & No change & No change & No change \\
\hline 9. Influences & No change & No change & No change & No change \\
\hline $\begin{array}{l}\text { 10. Dispute } \\
\text { resolution }\end{array}$ & No change & No change & No change & No change \\
\hline
\end{tabular}

On the other hand, the adoption of B2B in the Garak wholesale market comparatively has less effect on reducing costs although two processes are improved. In logistic process, delivery costs are reduced because the food products arrived directly to the buyer without delivery through a market place. Also, for the similar reason, inspection of products is conducted at the place of buyer such as buyer's distribution center instead of market place. Thus, the cost for authentication can be reduced. However, these cost reduction factors are not sufficient enough to change existing offline transaction method. 


\section{Conclusion}

In both cases of $\mathrm{B} 2 \mathrm{~B}$ e-commerce, the results show that some of the exchange processes are effectively replaced compared to the traditional process. However, B2B e-commerce of wholesale market was not successful in contrast with foodservice B2B e-commerce due to the differences of improved exchange processes. In successful case, search, valuation, and product representation processes provide users benefits such as time saving and cost reduction. Also, regular supplier inspection and association with certificate authority in the authentication process can develop trust in the transaction procedure. These successful factors result from an effort to change overall exchange processes. Mass food poisoning accident was serious problem in Korean society. So, adoption of B2B e-commerce can prevent this accident to happen again. Meanwhile, in failure case, the effect of B2B ecommerce adoption is not significant although logistics and authentication processes are improved. The main reason for this failure is that adoption of $\mathrm{B} 2 \mathrm{~B}$ e-commerce is only applied to changing existing transactions from offline to online. Thus, there is no benefit except the products are traded outside of market place.

The implication of this study is that exchange processes need to be considered carefully for successful B2B e-commerce adoption. A simple approach to transfer B2B transaction from offline to online is not appropriate. Adoption directer needs to consider adopting new B2B e-commerce which can create the value that the existing transactions do not provide. After that, the director needs to design B2B ecommerce system so that the effect of cost reduction can exceed desired benefit of all the transaction parties.

\section{Acknowledgement}

This research was supported by the MSIP (Ministry of Science, ICT and Future Planning), Korea, under the C-ITRC (Convergence Information Technology Research Center) (IITP-2015-H8601-15-1007) supervised by the IITP (Institute for Information \& communications Technology Promotion)

\section{References}

Agrinet 2015, 'Information about B2B in school foodservice food market 2014. 'Available form: <http://www.agrinet.co.kr/news/articleView.html?idxno=133769>'. [15 April 2015] .

Kambil, A \& Van Heck, E 1998, 'Reengineering the Dutch flower auctions: A framework for analyzing exchange organizations', Information Systems Research, vol. 9, no. 1, pp. 1-19.

doi: $10.1287 /$ isre.9.1.1

Kaplan, S \& Sawhney, M 2000, 'E-hubs: the new B2B marketplaces', Harvard Business Review, vol. 78, no. 3, pp. 97-106.

Mukhopadhyay, T \& Kekre, S 2002, 'Strategic and operational benefits of electronic integration in B2B procurement processes', Management Science, vol. 48, no. 10, pp. 1301-1313.

doi: $10.1287 / \mathrm{mnsc} .48 .10 .1301 .273$

Rauyruen, P \& Miller, KE 2007, 'Relationship quality as a predictor of B2B customer loyalty', Journal of business research, vol. 60, no. 1, pp. 21-31. doi: 10.1016/j.jbusres.2005.11.006

Seoul agro-fisheries \& food corporation 2013, Annual report, Seoul. 